\title{
Inaugural Professorial Lecture- Is Australian history still possible? Australia and the global eighties ${ }^{1}$
}

\author{
Frank Bongiorno \\ The Australian National University
}

It is a mark of the limiting character of a purely national perspective that it has been so rarely noticed that two English-speaking democracies of the 1980s each had a former trade union official as its national leader. Bob Hawke, Australian Labor Party (ALP) prime minister, was a former president of the Australian Council of Trade Unions (ACTU); Ronald Reagan, a former president of the Screen Actors Guild. Each is credited with having restored to their countries 'a sense of national pride and optimism. . In Reagan's case, his role was to lift the gloom that had descended over the country during the Carter presidency, with its economic decline and foreign humiliations; to demonstrate that in America, it was indeed morning again. In Hawke's, it was to take full advantage of the improving national mood in 1983 associated with the end of a drought and a recession, and the victory of an Australian syndicate in the America's Cup yachting competition in Newport, Rhode Island.

We should not exaggerate the similarities. Reagan had once been a Roosevelt 'New Deal' Democrat but he was now of the right. Hawke, having begun his ACTU presidency as the left's nominee, was now 'right' in the context of his formally 'democratic socialist' party but a pragmatist increasingly criticised by the left inside and especially outside the ALP as having abandoned Labor ideals and traditions. Each, however, was a charismatic and popular leader who had achieved celebrity outside formal politics-Reagan in show business, Hawke as a national union leader and media superstar who was as much a showman as Reagan. They both

1 Inaugural Professorial Lecture, The Australian National University, 10 May 2017. This version has been edited and amended in light of two astute referees' reports, for which the author is grateful, and the passage of time.

2 Michael Schaller, Reckoning with Reagan: America and Its President in the 1980s (Oxford: Oxford University Press, 1992), 66. 
appealed to voters above the formal structures of party and government, creating an almost mystical bond with the people which helped sustain a powerful sense of destiny. Yet destiny often needed helping along; each was flexible, being willing to compromise in ways that could be dismissed as mere expediency by their more ideologically committed allies and opponents, but which helps to account for their political longevity. ${ }^{3}$

The rise of transnational and global histories in the early twenty-first century sometimes obscures the reality that much-perhaps mosthistory being written about the modern world is still national. By 'national history' I do not mean 'nationalist history', although the categories can and do overlap. Historians with a popular following still perform the part of the storytellers of their tribe, a phrase I borrow gratefully from Iain McCalman; sometimes addressing their audience as 'we'; ${ }^{4}$ at worst, trading in familiar and comforting national stereotypes; at best, challenging familiar ways of thinking and seeing.

I am myself a national historian. Both of my recent books-a history of Australian sexuality since 1788 and a history of Australia in the 1980 s - take 'Australia' as their subject. ${ }^{5}$ But a national history that treats 'Australia' as its basic unit of study inevitably misses something of the contingency of such a category. 'Australia' is the product not only of a local political settlement but also of global and transnational forces such as imperial conquest and decolonisation, industrialisation, migration, the expansion of capital, the development of trade, and exchanges of information, knowledge, ideas and culture. The best national histories treat the nation-state as embedded in global networks shaped by these forces. But it remains a valid criticism that most national histories deal inadequately with such challenges. The mere telling of a story about 'the nation' can imply a singularity or exceptionalism, even a selfcontainment. ${ }^{6}$ We can easily miss the common elements in the leadership styles of a Reagan and a Hawke.

3 Frank Bongiorno, The Eighties: The Decade That Transformed Australia (Melbourne: Black Inc., 2015), 33-40, 58; John Ehrman, The Eighties: America in the Age of Reagan (New Haven: Yale University Press, 2005), 71-72.

4 See, for instance, Geoffrey Blainey, The Story of Australia's People: The Rise And Rise of a New Australia (Melbourne: Penguin, 2016), 142.

5 Frank Bongiorno, The Sex Lives of Australians: A History (Collingwood: Black Inc., 2012); and Bongiorno, The Eighties.

6 William O Coleman, ed., Only in Australia: The History, Politics, and Economics of Australian Exceptionalism (Oxford: Oxford University Press, 2016). 
My lecture is, in part, a reflection on these problems, which I discuss in reference to what I'm calling the global 1980s. The decade has received increasing historical attention as with the passage of time it passes from current affairs to contemporary history. Historians now seem increasingly confident in placing the 1980s in the context of a broader sweep of time. ${ }^{7}$ Some treat the decade as the end of an era in world history, placing 1989, and the end of the Cold War, alongside such momentous and revolutionary years as 1789 and $1917 .{ }^{8}$ Famously, beginning with a controversial article published in 1989 and culminating in a 1992 book, Francis Fukuyama declared that moment as 'The End of History', by which he meant that liberal democracy and capitalism had emerged as the only viable economic and political systems. There was a universal pattern discernible in 'History', and this was where it was going. Sure, there might be discontinuities along History's journey-the extinction of the dinosaurs and the rise of the Nazis were examples—but the process was coherent and unidirectional. "[W] have trouble imagining a world that is radically better than our own', he explained, 'or a future that is not essentially democratic and capitalist'.

There is little point in providing yet another critique of this flawed exercise in latter-day Hegelianism a quarter of a century after its publication. It is more pertinent to my purpose to suggest that the confidence and optimism of 'The End of History' thesis was probably only possible in the late 1980s and early 1990s, in those years between the fall of the Berlin Wall and 9/11, or perhaps before the genocides in east Africa and southeastern Europe of the mid-1990s. It is an artefact-a period piece, if you like-through which we can read the effects of rapid and far-reaching change that was unthinkable just a few years before. It is little wonder then that a recent American collection of essays on the decade calls the 1980s 'A Critical and Transitional Decade'. But that book is almost exclusively concerned with the US; Part 4, which promises to consider the world beyond America's borders, is meaningfully called "'We are the World", but there is little sign of any irony in the recycling of this well-known 1980s song title. ${ }^{10}$

7 EJ Hobsbawm, Age of Extremes: The Short Twentieth Century, 1914-1991 (London: Michael Joseph, 1994).

8 Kimberly R Moffitt and Duncan A Campbell, 'Introduction: The 1980s as a Decade', in The 1980s: A Critical and Transitional Decade, ed. Moffitt and Campbell (Lanham, Maryland: Lexington Books, 2011), 2.

9 Francis Fukuyama, The End of History and the Last Man (London: Penguin, 2012), 46, 128-30 \& 139.

10 Moffitt and Campbell, eds, The 1980s. 
Historical knowledge is not nationally neutral; a political economy of knowledge ensures that the histories of powerful Western countries as a rule do better in a global academic and publishing marketplace than those of smaller nations, to say nothing of the well-known divisions between the global North and South. It has been a feature of transnationalism in history that it has drawn renewed attention to the relevance of local or national stories to a larger scene. Localities—such as towns or cities-will sometimes figure in such histories as 'nodes' in a 'network', but in practice the histories of many places become invisible, or very nearly so. ${ }^{11}$

The contrast of this present rather ambiguous place for national history with what might be thought of as the 'golden age' of Australian history in the years between the 1960s and 1980s seems very stark. From the beginning of the 1960s, the end of empire, the eclipse of Australian Britishness and the emergence of the so-called new nationalism formed the background to the rise of Australian history. ${ }^{12}$ In many ways, the prominence of the subject in the public sphere reflected the generational experience of those who had come to adulthood in the 1950s and 1960s and felt there had been insufficient access to Australian culture in their formal education. More generally, Australian history was part of a declaration of independence from the British Empire; there were similar developments in Canada, New Zealand, India, the Caribbean and even, arguably, within Britain itself, with the rise of Scottish and Welsh nationalism. Yet, paradoxically, the rise of Australian history from the 1960s to the 1980s coincided with the rise of a critical social history, stimulated by international influences, that gave voice and agency to women, Indigenous people, the working class, immigrants, and ethnic and sexual minorities. The preoccupations of the 'new social history' presented Australian history with a strangely divided personality. It fostered a sense of national distinctiveness and belonging, even as it drew attention to diversity, exclusion and discrimination and cast a critical eye over national stereotypes. This was a creative tension, although one that paved the way for historical transnationalism once the nationalist impulses that had given rise to the Australian history boom took a rather different turn in an age of more intense globalisation during the 1990s.

11 Frank Bongiorno and Erik Eklund, 'The Problem of Belonging: Contested Country in Australian Local History', New Scholar: An International Journal of the Humanities, Creative Arts and Social Sciences 3, no. 1 (2014), 39-40.

12 Jim Davidson, 'The De-dominionisation of Australia', Meanjin 38, no. 2 (July 1979), 13953; Stuart Ward, Australia and the British Embrace: The Demise of the Imperial Ideal (Melbourne: Melbourne University Press, 2001); James Curran and Stuart Ward, The Unknown Nation: Australia After Empire (Melbourne: Melbourne University Press, 2010). See also “"Post-Imperial” Australia', Special issue, Australian Journal of Politics and History 51, no. 1 (2005). 
In the 1980s, however, the boom was in full swing. Books about the Australian past appeared in vast numbers on an ever-growing variety of subjects, including in the genres of Aboriginal family history, autobiography and memoir-think of the success of Sally Morgan and Ruby Langford Ginibi. Peter Carey's Booker prize-winning historical novel, Oscar and Lucinda, was set largely in colonial New South Wales and climaxed in an exploration party's massacre of Indigenous people. ${ }^{13}$ Convict history seemed to do particularly well around the time of the Bicentenary of 1988, with historians such as Robert Hughes and Babette Smith writing very different kinds of books on the era. ${ }^{14}$ Anzac began its modern meteoric rise, launched in 1981 by the success of Peter Weir's film Gallipoli and Albert Facey's book A Fortunate Life, later a television mini-series. ${ }^{15}$ Historians - a few of them at least-were seen frequently in the media; they were as ubiquitous then as specialists in terrorism, international relations and strategic studies are today. TV mini-series screened on a bewildering variety of historical topics. The First Fleet re-enactment would soon be sailing into Sydney Harbour, Coca-Cola logo and all. The Australian National University's own Manning Clark wandered the land as the Bicentennial celebrity par excellence, his sixvolume History even becoming the subject of a stage musical. Clark looked and sounded like an Old Testament prophet: how was it that in a country seen as secular-minded, egalitarian, democratic, informal and even anti-intellectual, Clark-with his searching spirituality, his wellhoned biblical language and his cryptic literary allusions - came to achieve this strange status? Possibly the national stereotype itself is flawed; that many Australians of the 1970s and 1980s had a remarkably old-fashioned hunger for a dignified national symbolism that could be taken seriously by 'old' countries. Here was evidence that Australia had a conscience and a soul. And his books, in their stately dust-jackets - they would not have been out of place next to the family Bible_-showed that Australia also had a history, that it was not just an obscure footnote to the British Empire. ${ }^{16}$

13 Sally Morgan, My Place (Fremantle: Fremantle Arts Centre Press, 1987); Ruby Langford, Don't Take Your Love to Town (Ringwood: Penguin, 1988); Peter Carey, Oscar and Lucinda (St Lucia: University of Queensland Press, 1988).

14 Robert Hughes, The Fatal Shore: A History of the Transportation of Convicts to Australia, 1787-1868 (London: Collins Harvill, 1987); Babette Smith, A Cargo of Women: Susannah Watson and the Convicts of the Princess Royal (Kensington: New South Wales University Press, 1988).

15 Albert Facey, A Fortunate Life (Fremantle: Fremantle Arts Centre Press, 1981).

16 Mark McKenna, An Eye for Eternity: The Life of Manning Clark (Carlton: The Miegunyah Press, 2011), 613-16. 
The most influential contributions to understandings of the 1980s are the work of journalists rather than professional historians: notably Paul Kelly, editor-at-large for The Australian. In Australia journalists have been more willing than historians to write of the recent past. Their professional work provides them with a public profile, and with contacts, stories and files that, with much or little effort, can be translated into book-length publication. Certainly, Kelly's The End of Certainty: The Story of the 1980s (1992) remains the most influential account of Australia in that decade. ${ }^{17}$ Kelly tells his story in terms of its movers and shakers. It is largely the view from Canberra's Parliamentary Press Gallery, with all of the benefits, and the limitations, of such a perspective.

Kelly's was a contemporary history in almost every sense one might imagine, appearing in 1992 when the 1980s were a recent memory and, for many, an unhappy one because they seemed a time of corporate greed and policy failure that led to a nasty recession. But Kelly sets the 1980s in a wider context - the rise and fall of what he calls 'the Australian Settlement' in the 90 years between 1901 and 1991-and much of its intellectual power comes out of that manner of framing his 1980s narrative. For Kelly, the decade mattered because it had seen a Labor government open up the economy to the world, deregulating the financial sector, reducing tariff protection, decentralising the industrial relations system and selling public assets. Yet, for all its emphasis on Australia's integration into the world economy, Kelly's story is a national one, addressed to a national audience, and designed to produce national effects; that is, to persuade Australians of the wisdom of the changes the previous decade had wrought and to urge them to support a politics that would extend them in the 1990 s. $^{18}$ Kelly assumes the role of a kind of tribal storyteller, addressing the 'imagined community' of the nation about its past and prospects. ${ }^{19}$

My own approach to Australia's 1980s treats the Hawke Labor Government as also very much a response to the economic, political and cultural challenges of the 1980s. Bob Hawke's election policy speech in February 1983 gave few signs of the dramatic changes that would mark the Labor Government's 13 years in office, especially in the direction of what contemporaries called 'economic rationalism' and which is now

17 Paul Kelly, The End of Certainty: The Story of the 1980s (St Leonards: Allen \& Unwin, 1992).

18 Kelly, The End of Certainty, 679-85.

19 Benedict Anderson, Imagined Communities: Reflections on the Origin and Spread of Nationalism (London: Verso, 1983). 
more commonly known as 'neoliberalism'. Responding to the recession of 1982-83, Labor's election policy was recognisably Keynesian as well as protectionist; increased spending would revive a faltering economy, and a recession which had seen the loss of thousands of manufacturing jobs was no time for tariff cuts. ${ }^{20}$

Yet, almost from the moment Labor came to power, it shifted from this traditional approach, with both Hawke and the Treasurer, Paul Keating, worrying that excessive spending would lead to the very kind of inflationary break-out that had played such a large role in destroying both the Whitlam and Fraser governments. Keynesian economists and advisers soon found themselves on the outer. The most spectacular changes occurred initially in the Australian financial sector, where the government floated the dollar in December 1983-a decision recognised then, and even more forcibly since, as a critical moment in the making of modern Australia-followed by a decision in 1984 to allow foreign banks to begin operating locally. At the same time as it subjected the economy and its own decision-making ever more closely to the judgement of the global market, the new government self-consciously cultivated an image of fiscal rectitude, seeking to place as much distance as it could between itself and the Whitlam Government. It moved away from that government's emphasis on universalism in welfare, with the notable exception of a new system of health insurance, Medicare. ${ }^{21}$

Many of these changes were disorientating because they were introduced by a Labor Party that had historically sought to control rather than unleash market forces. But Australia's shift towards deregulation was anything but exceptional. Such changes occurred across the world, most famously in the case of Britain under Margaret Thatcher and the US under Ronald Reagan. ${ }^{22}$ The advance of the market occurred irrespective of whether the centre-left or the centre-right held office. ${ }^{23}$ The case of France is particularly instructive because the shift seemed so unlikely when Socialist

\footnotetext{
20 Bongiorno, The Eighties, 4.

21 Bongiorno, The Eighties, 40-50, 158.

22 Henk Overbeek and Kees van der Pijl, 'Restructuring Capital and Restructuring Hegemony: Neo-liberalism and the Unmaking of the Post-war Order', in Restructuring Hegemony in the Global Political Economy: The Rise of Transnational Neo-liberalism in the 1980s, ed. Henk Overbeek (London: Routledge, 1993), 2: doi.org/10.4324/9780203411865.

23 Herman M Schwartz, 'Public Choice Theory and Public Choices: Bureaucrats and State Reorganization in Australia, Denmark, New Zealand, and Sweden in the 1980s', Administration \& Society 26, no. 1 (May 1994), 48-77: doi.org/10.1177/009539979402600104.
} 
President François Mitterrand came to power in May 1981. ${ }^{24}$ Policies of the early years included nationalisation, public sector expansion, a lower retirement age, a shorter working week, more paid holidays, increased minimum wages, pro-union labour laws and a wealth tax. But inflation remained high and the country suffered a foreign exchange crisis that culminated in a decision to devalue the franc in March 1983. Australia, it might be noted, devalued in the same month, as one of the first decisions of the new Labor Government. A 'Socialist U-turn' followed in France, a policy of 'austerity'. During the period of 'cohabitation' in the mid1980s — that is, a Socialist Party President, Mitterrand, and a conservative prime minister, Jacques Chirac-industries that had been nationalised in the early 1980s were privatised. Chirac also cut taxes and spending, abolished price controls and introduced labour market reforms. ${ }^{25}$

The parallels with the Australian story seem fairly obvious. Indeed, the realisation that in an age of globalisation it was impossible for any particular country to follow its own course without due regard for the economic world bequeathed by the end of the long boom took a distinctive form in each country. Nonetheless, the transnational neoliberal revolution can be traced in economic histories of the era as diverse as those of Spain, Ghana, Chile and New Zealand, to say nothing of China's market reforms under Deng Xiaoping.

In the fields of culture, consumption and technology, too, where a transnational or global story seems nearly unavoidable, it is nonetheless surprising how wedded historical interpretation remains to national perspective. ${ }^{26}$ The major new technologies of home and work, such as the video cassette recorder (VCR), the fax machine and the personal computer, can only be understood in the context of global consumer capitalism. True, the fax machine was a particularly revolutionary technology in Japan because of the ease with which images of Japanese characters could be communicated, but it was hardly less so in Australia, where the number of units in the country expanded from something like 8,000 to 50,000 between 1984 and 1987. It was a major boon for a place

24 Philip Short, A Taste for Intrigue: The Multiple Lives of François Mitterrand (New York: Henry Holt, 2013), 312-13, 322 \& 361.

25 Short, A Taste for Intrigue, 361-76, 392-96, 422-23, 431-36, 443, 464 \& 484-86; Jeffrey Sachs and Charles Wyplosz, 'The Economic Consequences of President Mitterrand', Economic Policy 1, no. 2, (April 1986), 261-306: doi.org/10.2307/1344559.

26 Bob Batchelor and Scott Stoddart, The 1980s (Westport: Greenwood Press, 2007). 
so distant from the world's major markets. ${ }^{27}$ The VCR was also becoming ubiquitous, climbing from one in 20 Australian households early in the decade to more than half by $1987 .{ }^{28}$ Personal computers spread across homes and workplaces as they became cheaper, in the process helping to create the global phenomenon of Julian Assange, a teenager in the mid1980 s but already a confirmed computer geek soon after acquiring his first Commodore 64 . He would become the twenty-first century's ultimate celebrity global citizen, rivalled in that status only by another Australian who, in 1985, swapped his Australian for American citizenship to expand his media empire: Rupert Murdoch. ${ }^{29}$

Other Australian cultural exports made their mark in this globalising world, with the export of TV soaps such as Neighbours, of the hit film Crocodile Dundee, and of pop groups such as INXS and Midnight Oil. The British critic, Peter Ackroyd, described Crocodile Dundee, starring the comedian Paul Hogan, as 'a heavily Americanised film':

Dundee, wearing his Australian version of the stetson, acts like some representative of the old cowboy and thus reminds the American cinema audience of its more manly, heroic and (at least in his case) goodhumoured past. ${ }^{30}$

Like Hogan and Dundee, the rock group INXS was a huge hit in the US, perfectly in tune with the MTV generation. 'Their music concerns itself with many of the stock concerns of the genre', an acerbic critic commented in Britain's New Musical Express. 'Lyrically there are obligatory references to red dresses, long black hair, wantin' and needin', but the market values of FM and MTV have brought with them this new kind of rock'. ${ }^{31}$ The more blatantly political Midnight Oil's engagement with nuclear and environmental issues inevitably gave them a transnational sensibility. They flourished in the United States of Reagan and Bush Senior, thereby bringing to the attention of young American audiences the oppressions suffered by Indigenous people, asbestos miners and other victims of injustice in distant Australia. ${ }^{32}$

27 Bongiorno, The Eighties, 209-10.

28 Bongiorno, The Eighties, 211.

29 Bongiorno, The Eighties, $236 \& 122-23$.

30 Peter Ackroyd, 'Australian Fantasies', Spectator 3 (January 1987), 30.

31 Stuart Maconie, 'INXS: "You British Are Too Cool For Your Own Good”, New Musical Express 25 (June 1988), 14.

32 Peter Garrett, Big Blue Sky: A Memoir (Sydney: Allen \& Unwin, 2015). 
A properly transnational history of the US in the 1980s that ignored Mick Dundee would surely overlook one of that country's dream-heroes, a figure fit to take his place beside Reagan, and as evocative of the nostalgic fantasy that historians have identified as a powerful strain of the era. ${ }^{33}$ Similarly, a properly transnational history of Britain would need to make room for Neighbours, which assumed a notable place in the dream-life of Thatcher's Britain. Transnational perspectives will not supersede national histories of the 1980s nor, indeed, of any other era, but national histories will be the poorer for their failure to take full account of research attuned to the transnational and the global.

You can, if you wish, try to forget about the eighties, but, as the rise of that quintessentially eighties 'American Man' Donald Trump would suggest, the eighties do not wish to forget about us. Given the decade's ubiquity in both the nostalgia industry and in public discourse, we are unlikely to be able to forget about the 1980s entirely, but there is a politics of memory in which we are enjoined to do our best to overlook some things while recalling others-sometimes through rose-tinted glasses that can make them virtually unrecognisable to anyone who bothers researching the era. As Dennis Glover has recently reminded us in his affectionate, angry, nostalgic, elegiac and moving book about his home-town of Doveton in outer-suburban Melbourne, there is a 1980s 'reform' cheer-squad, led by the two Pauls, Kelly and Keating, that enjoins us to forget the reality-still so evident in the post-industrial landscapes of many communities - that the decade had its 'losers', those with skills not valued in the post-eighties, post-recession, deregulated economy. ${ }^{34}$

One of my own students in an economic history class, after I had explained that there were Australian industrial suburbs and towns with a rate of unemployment above 15 per cent in the 1980s, asked how such communities had recovered. The sad answer, of course, is that many still have not; indeed, some face further ordeals as Australian car manufacturing ends and steel-making comes under increasing pressure. There was a telling moment in the series of interviews that Kerry O'Brien conducted with Paul Keating for the $\mathrm{ABC}$, in which O'Brien asks the former Treasurer about those whose jobs were forever wiped out by

33 Michael Dwyer, 'Fixing" the Fifties: Alex P. Keaton and Marty McFly', in Moffit and Campbell, eds, The 1980s, 201-23; Batchelor and Stoddart, The 1980s, xiii.

34 Dennis Glover, An Economy is Not a Society: Winners and Losers in the New Australia (Collingwood: Redback, 2015). See also Mark Peel, Good Times, Hard Times: The Past and the Future in Elizabeth (Melbourne: Melbourne University Press, 1995). 
industry restructuring under Labor: 'And do you know what they found?' Keating replies, 'A better job a week later, in a growing economy with big employment growth'. 'You make it sound so simple', replies a sceptical O'Brien. ${ }^{35}$ And so he does: Keating, that great political salesman, wants us to remember the 1980 s, but he also wants us to do some forgetting, too.

$\mathrm{He}$ is not alone there. We can be fairly certain that in this post-Mabo age of sweetness and light in relations between mining companies and Indigenous people —or at least some of them — the mining industry does not want us to remember too vividly the days when its anti-land rights television advertising showed a black hand building a brick wall across a map of Western Australia containing the warning:

\section{KEEP OUT \\ THIS LAND IS UNDER \\ ABORIGINAL \\ CLAIM}

And it would be no more polite to recall mining executive Hugh Morgan's denigration of Aboriginal culture as barbaric and cannibalistic. ${ }^{36}$

And then there is the Melbourne historian Geoffrey Blainey, who tells media interviewers these days of his role in campaigning against the pace of Asian immigration to Australia in the 1980s: 'I was simply saying that social cohesion is important'. ${ }^{37}$ This may well be how Blainey now recalls his role in a highly emotional debate, but it is a sanitised summary. Beginning with the dubious claim that Asians represented 'the favored majority' in Australia's immigration policy, Blainey later went on to condemn the Hawke Government for its 'Asianisation' and 'Surrender Australia' policies. He cited South Africa under apartheid as an example of a failed multicultural society. His image of recent immigration history crystallised as one of discrimination against British and European applicants, of Asians being preferred for government jobs, of a 'secret room' in Canberra where officials manipulated Australia's immigration intake, of ordinary Australian working people turned in to 'refugees', outcasts and strangers in

35 Kerry O’Brien, Keating (Crows Nest: Allen \& Unwin, 2015), 318.

36 Ronald T Libby, Hawke's Law: The Politics of Mining and Aboriginal Land Rights in Australia (Nedlands: University of Western Australia Press, 1989), 76-77; Hugh Morgan, 'Religious Traditions, Mining and Land Rights', in The Land Rights Debate: Selected Documents, ed. Ken Baker (Melbourne: Institute of Public Affairs, 1985), 22-26.

37 Richard Guilliatt, 'He's Got History', Weekend Australian Magazine, 29-30 October 2016, 15. 
their own land. ${ }^{38}$ Liberal Party leaders flirted with Blainey's ideas, briefly in 1984 and then again in 1988, when John Howard fatally (for his own leadership) decided to make an issue of the pace of Asian immigration. Bipartisanship over immigration and multiculturalism largely held but in the longer run, the image of neglected and alienated 'old Australians' championed by Blainey has been resilient. Today, it finds expression in the melancholy image of a betrayed and abandoned white working class at the heart of conservative politics, whether in Trump's America, Brexit England, or among the Hansonite minority in Australia. And in a peculiarly rural form, it figures in the effort of National Party leader Barnaby Joyce to articulate a basis for the revival of his stalled political career. ${ }^{39}$

The historians of the post-World War eclipse of Britishness in Australia now often treat the 1960s as the critical turning point in the country's civic identity. In some accounts the period appears almost as one of existential crisis, as Australians took their place among the abandoned Britons left high and dry by the United Kingdom's turn to Europe. Yet in the 'new' nationalist rhetoric of the 1960s and 1970s, one searches in vain for a sense that Australia would cease to be a white nation. The language of Britishness went into decline, and an explicit language of whiteness with it. But the widespread assumption, until the mid-1970s and the appearance of large numbers of Asian migrants in the wake of the Vietnam War, was that Australia could engage with Asia and abandon its offensive White Australia Policy without fundamental change to its essential whiteness and Western-ness. ${ }^{40}$ This helps explain the kinds of anxieties that emerged in the 1980s, by which time it was clear that more fundamental changes were occurring. In my reading, the 1980s becomes a turning point in the history of Australian national identity, the moment when, as Ghassan Hage has so vividly put it, the appearance of 'Third World Looking People' in Australian streets began to raise more fundamental questions about national selfhood than those suggested by the liquidation of the British Empire in the 1960s. ${ }^{41}$

38 Warrnambool Standard, 19 March 1983, Age, 20 March 1984, Herald, 3 April 1984, West Australian, 9 June 1984, in The Immigration Debate in the Press 1984, ed. Renata Singer, assisted by Michael Liffman (Richmond: The Clearing House on Migration Issues, 1984), 3, 6, 18 \& 59; and Geoffrey Blainey, All for Australia (North Ryde: Methuen Haynes, 1984), especially Chapters 6 \& 7.

39 Barnaby Joyce, Weatherboard and Iron: Politics, the Bush and Me (Sydney: New Holland, 2018).

40 Curran and Ward, The Unknown Nation.

41 Ghassan Hage, White Nation: Fantasies of White Supremacy in a Multicultural Society (Annandale: Pluto Press, 1998). 
But there are also other, more immediate political issues at stake in how we remember. The dilemmas, conflicts and habits of thought that we find in the 1980s still cast their shadow over our own times. We are still being enjoined to worry over threats to national cohesion posed by the latest wave of migrants, with religion intersecting with—and arguably now overwhelming — race as the key signifier of difference. ${ }^{42}$

What I want to suggest in the final part of this lecture is that among the most fundamental responsibilities of the national historian is to seek to influence public consciousness with stories that are both true and engaging, and yet sometimes uncomfortable and unsettling. For those who look to the past for a vindication of their own selfhood or past behaviour, the work of historians committed to honest and painstaking historical enquiry can be threatening. To conservative nationalists, such work can look like a dubious form of self-indulgence on the part of over-educated and taxpayer-funded idiots and, even worse, as a threat to Team Australia. We hear this sentiment being expressed every April in complaints about academic historians who challenge this or that aspect of the Anzac legend. Yet, notwithstanding the complications added by claims concerning Anzac's sacredness, the familiar complaints about disloyal academic assaults on Anzackery are really just a special example of a familiar attitude: the idea that histories of the national past should be patriotic, tidy and usable.

Some of these issues arose in one of the more thoughtful reviews of my book The Eighties, that in the Weekend Australian by David Free. Bongiorno, he wrote:

retrieves the forgotten voices of the not-so-great, an approach that is known in the trade as 'history from below'. Whether these voices are always worth reviving is debatable [...] Such stuff is the white noise of Australian politics, the dust that had to settle before we could start seeing things in perspective. What do we gain by kicking it up again? Should it fundamentally change our minds about the past?

Free worries that I might be suggesting 'that revisiting the past from below is not merely a useful supplement to hindsight but a revolutionary new way of seeing that trumps the naive journalistic practice of looking at history

42 For a study of this transition, see Alexandra Biggs, "Islam in the Antipodes: Australian Mosque-Building and the "Muslim Migrant" 1967-1990' (BA Honours thesis, School of History, The Australian National University, 2016). 
backwards'. Apparently, this is 'a piece of academic theory being pushed too far. To what degree, exactly, are our retrospective judgments obliged to capture what people felt back then, in the heat of the moment?' ${ }^{43}$

The answer to that one is 'to a very great degree', unless you want to write bad history. The great British historian, EP Thompson, is able to help us out here. 'Our only criterion of judgement', he says in the famous preface to The Making of the English Working Class (1963):

should not be whether or not a man's actions are justified in the light of subsequent evolution. After all, we are not at the end of social evolution ourselves. In some of the lost causes of the people of the Industrial Revolution we may discover insights into social evils which we have yet to cure. ${ }^{44}$

So, for Thompson, we should try to understand people's actions in light of their own experience and circumstances, rather than assimilating it to the history of what happened next. Paradoxically, in doing so, we are invited to relativise the present, to see our own perspectives and judgements as contingent, indeed as phenomena that might in due course become subject to the condescending or, if posterity is kind to us, the empathetic judgement of future historians.

Nonetheless, the perspective provided by the passing of time also has its role to play, even when, as I do, we write of a past in the living memory of many of us. At one point in his review, Free compares my own treatment of the 1980s to Kelly's in The End of Certainty: 'Bongiorno favours the sympathetic close-up; Kelly takes the chillier long view. And surely the long view, in history and politics, is what matters [...] Individual pain matters, but the bigger picture, the retrospective wide shot, matters more. ${ }^{45}$ Again, I disagree: in good history-and certainly in good democratic historythey both matter a very great deal.

This is perhaps especially so in the study of the nation, where-as the French historian Ernest Renan suggested in a famous lecture in 1882the ethical responsibility of the historian to disclose national forgetfulness is critical. 'Forgetting, I would even say historical error', Renan argued:

43 David Free, 'Short Memory', Weekend Australian Review, 31 October - 1 November 2015, 19.

44 EP Thompson, The Making of the English Working Class (Harmondsworth: Penguin, 1968 [1963]), 13.

45 Free, 'Short Memory', 19. 
is an essential factor in the creation of a nation and it is for this reason that the progress of historical studies often poses a threat to nationality. Historical inquiry, in effect, throws light on the violent acts that have taken place at the origin of every political formation, even those that have been the most benevolent in their consequences. Unity is always brutally established. ${ }^{46}$

In the case of Australia, the process of 'historical error' and the habit of 'forgetting' are now perhaps best appreciated in relation to the history of violence against Indigenous people, and of what WEH Stanner influentially called 'The Great Australian Silence'. ${ }^{47}$ This forgetfulness lies at the heart of the denialism that enjoins us all to celebrate Australia Day each 26 January as an expression of our common belonging, as if we can all regard British settlement as an unalloyed benefit to humanity. But the urge to forget is also at the heart of debates over the 1980 s, which are to be celebrated as an era of brave and intelligent economic reform with a human face, but not as a decade of resilient anxiety about Asian migrants and Japanese investors, of unfulfilled promise to Indigenous people, or of an excess that ended in a recession which devastated vulnerable communities and destroyed livelihoods. As Thompson said of the casualties of the English Industrial Revolution, we should not regard such 'casualties of history' only as 'the lost myriads of eternity'. ${ }^{48}$

Quite late in my research on The Eighties, I became absorbed in some records in the National Archives of Australia on the Bicentenary. They were collected by the official historian of the Bicentenary, Denis O'Brien, who wrote to country newspapers in 1988, asking people to let him know what they had done on 26 January. The letters reveal that alongside the formal, official and organised events, people did things in their own way, with an emphasis on the sociable, playful celebration of a nation that, they said, made them feel grateful and proud. There were evasions of the darker aspects of Australian history-such as the dispossession of Indigenous people_-as well as engagements with it. I loved this material, not least because it confirmed for me that there was a 'history from below'

46 Ernest Renan, 'What is a Nation?', text of a conference delivered at the Sorbonne on 11 March 1882, in Ernest Renan, Qu'est-ce qu'une nation?, translated by Ethan Rundell (Paris: Presses-Pocket, 1992), accessed at ucparis.fr/files/9313/6549/9943/What_is_a_Nation.pdf.

47 WEH Stanner, After the Dreaming: Black and White Australians-An Anthropologist's View (Sydney: Australian Broadcasting Commission, 1969), 18-29.

48 Thompson, Making, 13 \& 915. 
still to be written about 1988, an enduring folk life only mildly influenced by the corporate branding of the Australian Bicentennial Authority and the controversies that had engaged the elites.

There is something oddly poignant about many of these personal stories, perhaps because so many writers wove their intimate experience and feelings for home, family, friends and country around their accounts of the national celebrations. My favourite concerns Tracey Matthies, a countrytown journalist and mother from Leongatha who, after describing a busy day of juggling her multiple roles—such a common story of gender in the 1980s-concluded:

Many people have said our bicentennial marks the end of one era and the beginning of a new one for our nation. In retrospect, I see the same can be said for my family. On January 27, the day after Australia Day, Daley took his first steps and moved from babyhood to toddlerhood. ${ }^{49}$

This should not be dismissed as 'white noise', or an unfortunate distraction from the big picture, the wide pattern, the 'chillier longer view'. Rather, it is an Australian woman making meaning of her own professional, personal and family life in the context of a wider and more abstract connection; in this case, to the nation itself. I feel an intense privilege, and responsibility, when someone affords me such a precious glimpse of her life, and such a rare insight into her sense of belonging.

49 TG Matthies to Denis O’Brien, 10 May 1988, 'The Book of the Year-Regional Newspapers \& Readers Involvement', National Archives of Australia, NAA: C2705, PA50-3442, PART 2. 
This text is taken from ANU Historical Journal II: Number 1, published 2019 by ANU Press, The Australian National University, Canberra, Australia.

doi.org/10.22459/ANUHJII.2019.15 